\title{
Peripheral blood toll-like receptor 4 correlates with rapid virological response to pegylated-interferon and ribavirin therapy in hepatitis $C$ genotype 1 patients
}

Chuan-Mo Lee ${ }^{1,2}$, Tsung-Hui Hu ${ }^{1,2}$, Sheng-Nan Lu' ${ }^{1,2}$, Jing-Houng Wang ${ }^{1,2}$, Chao-Hung Hung ${ }^{1,2}$, Chien-Hung Chen ${ }^{1,2}$ and Yi-Hao Yen ${ }^{1,2^{*}}$

\begin{abstract}
Background: Toll-like receptors (TLRs) are effectors of the innate immune system that are able to recognize hepatitis $C$ virus ( $\mathrm{HCV}$ ) and give rise to an immune response. Failure of interferon (IFN)-a-based treatment is related to host immunity. Therefore, we sought to study the clinical importance of TLRs in HCV genotype 1 patients who received pegylated IFN (PEG-IFN) plus ribavirin (RBV) therapy.

Methods: We enrolled 79 treatment-naïve patients with HCV genotype 1. Patients completed a 24- to 48-week course of response-guided therapy. Peripheral blood monocyte (PBMC) expression of mRNA for TLRs 2, 3, 4, 7, and 9 was quantified by real-time PCR before therapy. TLR mRNA expression is shown as a log ratio relative to GAPDH mRNA $\left(\log 2^{-(\Delta C t)}\right)$.

Results: Forty-five patients (57.0\%) showed a rapid virological response (RVR). Univariate analysis revealed that TLR $2,3,4,7$, and 9 were significantly lower in the RVR group than in the non-RVR group $(P=0.001,0.014,<0.001,0$. 008, and 0.001, respectively). Multivariate analysis revealed that TLR $4<-2 \log (\mathrm{OR}: 7.17,95 \% \mathrm{Cl}: 1.70-30.34, P=0$. 007) was an independent predictor for RVR. In addition, levels of TLR 2, 3, 4, 7, and 9 were positively correlated with HCV viral load $(P=0.009,0.013,<0.001,0.007$, and 0.001 , respectively).

Conclusions: A low level of TLR 4 mRNA in PMBCs was correlated with RVR, which indicates that TLR4 may play a critical role in HCV recognition and activation of innate immunity. TLR expression levels were correlated with HCV viral load, indicating that TLR activation upon exposure to HCV may subsequently limit HCV replication.
\end{abstract}

Keywords: Hepatitis C virus, Toll-like receptor, Rapid virological response

\section{Background}

Hepatitis C virus (HCV) is a blood-borne, hepatotrophic virus that establishes a chronic HCV infection in up to $85 \%$ of cases [1]. With an estimated $2 \%$ of the global population infected with $\mathrm{HCV}$ [2], which carries the potential for chronic infection leading to cirrhosis, end-stage liver diseases, and hepatocellular carcinoma (HCC), it poses a considerable health risk [3-6].

\footnotetext{
* Correspondence: cassellyen@yahoo.com.tw

'Division of Hepatogastroenterology, Department of Internal Medicine,

Kaohsiung Chang Gung Memorial Hospital, 123 Ta Pei Road, Niao Sung Dist. 833, Kaohsiung City, Taiwan

${ }^{2}$ School of Medicine, College of Medicine, Chang Gung University, Taoyuan, Taiwan
}

Non-alcoholic fatty liver disease (NAFLD) is now increasingly being recognized as a cause of end-stage liver disease and is associated with increased rates of HCC, liver transplantation, and death [7-9]. Current population based prevalence of NAFLD is approximately $70 \%$ in people with type 2 diabetes mellitus (DM) [10]. Further, a recent study showed that liver transplant recipients with non-alcoholic steatohepatitis (NASH) have a higher risk of de novo post-transplant DM. This suggests the presence of an underlying metabolic disorder beyond fatty liver that may be causative for both NASH and type 2 diabetes [11]. 
Infection with HCV genotype 1, the prevalent genotype in Taiwan, Japan, and Southern and Eastern Europe [12-16], is predictive of a poor response to interferon (IFN)-based therapy. The sustained virological response (SVR) is $50-80 \%$ following combination therapy with pegylated interferon (peg-IFN) plus ribavirin (RBV) for 48 weeks [17-20].

The European Association for the Study of the Liver (EASL) and the American Association for the Study of Liver Diseases (AASLD) guidelines [21, 22] both suggest direct antiviral agents (DAAs) as the first line of therapy for patients infected with genotype 1 . However, the SVR rate can reach $76 \%$ after 48 weeks of peg-IFN plus RBV therapy in Taiwanese patients with genotype 1 [20], and peg-IFN plus RBV therapy remains the standard of care in Taiwan. Therefore, it is crucial to determine the mechanism of treatment failure for IFNbased therapy in Taiwan.

Host immunity is an important factor that is related to the failure of IFN- $\alpha$-based treatment. The innate immune system is particularly relevant in viral infections [23]. Toll-like receptors (TLRs), as effectors of the innate immune system, are activated immediately upon exposure to infectious agents and may subsequently limit replication of infectious agents [24].

TLRs belong to a family of cell receptors that are present on mammalian cells, and that are able to recognize several pathogen-associated molecular patterns (PAMPs) present on microbes [25]. Various viral components (RNA, viral proteins, and intact virions) can be recognized as PAMPs by the immune system; recognition can give rise to an immune response [25], including up-regulation of IFN- $\alpha$ production [23]. This may induce enhanced expression of IFN- $\alpha$-inducible genes, most of which perform important antiviral and immune regulatory functions. In vitro studies have indicated that, of the 11 human TLRs identified so far, TLR 2, 3, 4, 7, and 9 recognize specific HCV viral components as PAMP ligands [26-33].

Whether TLR expression is associated with a virological response in patients infected with HCV genotype 1 remains unclear. In this study, we investigated whether TLR expression on peripheral blood monocytes (PBMCs) is associated with virological responses to peg-IFN plus RBV therapy in patients infected with HCV genotype 1.

\section{Methods}

\section{Patients}

We enrolled 79 treatment-naïve patients with HCV genotype 1 , who then completed a 24- to 48-week course of response-guided therapy (RGT) with peg-IFN plus RBV. The RGT received was simply part of standard care in Taiwan and was funded by the Bureau of National Health Insurance, Department of Health, Taiwan. RGT was performed as follows: 24-week therapy for patients with rapid virological response (RVR) (defined as undetectable HCV RNA at week 4); 48-week therapy for patients with early virological response (EVR) (defined as detectable HCV RNA at week 4 and a $>2$-log decrease in HCV RNA at week 12); therapy was stopped at week 12 for patients with a null response (defined as a $>2$-log decrease in HCV RNA at week 12). PegIFN $\alpha-2 b$ (PegIntron, Schering-Plough Corporation, Kenilworth, NJ) at $1.5 \mu \mathrm{g} / \mathrm{kg}$ or PegIFN $\alpha$-2a (Pegacys, Roche, Basel, Switzerland) at $180 \mu \mathrm{g}$ was given subcutaneously once weekly. RBV was given at $1000 \mathrm{mg} /$ day for patients with a body weight of $\leq 75 \mathrm{~kg}$ and $1200 \mathrm{mg} /$ day for those $>75 \mathrm{~kg}$. Forty five patients achieved RVR, 34 patients did not. The characteristics of non-RVR group patients were as follow: there were 19 male and $15 \mathrm{fe}$ male, the median age was 53.4 years, the median body mass index (BMI) was $26.4 \mathrm{Kg} / \mathrm{m}^{2}$, the median Alanine Aminotransferase (ALT) was $84.5 \mathrm{IU} / \mathrm{L}, 28$ patients had high viral load $\left(\geq 4 \times 10^{5} \mathrm{IU} / \mathrm{ml}\right), 6$ patients had liver crrhosis, 24 patients had rs12979860 CC genotype, and 24 patients with good drug adherence.

Patients who were positive for anti-HCV antibody, assessed by third-generation enzyme-linked immunosorbent assay, were diagnosed with chronic hepatitis C; the diagnosis was confirmed by detection of serum HCV-RNA. Patients were excluded if they tested positive for serum hepatitis B surface antigens, anti-HIV antibodies, or exhibited other causes of hepatocellular injury (e.g., any history of alcoholism, autoimmune hepatitis, primary biliary cirrhosis, or treatment with hepatotoxic drugs).

HCV RNA was qualitatively detected using a PCRbased assay (Cobas Amplicor Hepatitis C Virus Test, version 2.0, Roche Molecular Systems, Branchburg, NJ, USA), which has a lower limit of detection of approximately $50 \mathrm{IU} / \mathrm{mL}$. HCV RNA was quantified by realtime PCR-based assay (COBAS AmpliPrep/COBAS TaqMan HCV Test, Roche), with a dynamic range of 43 to $69,000,000 \mathrm{IU} / \mathrm{ml}$. Genotyping of $\mathrm{HCV}$ was performed using a Siemens Diagnostics Versant $\mathrm{HCV}$ Genotype Assay. SVR was defined as serum HCV RNA undetectable at week 24 after treatment.

\section{PBMC preparation and RNA extraction}

PBMCs were isolated by Ficoll-Hypaque density gradient centrifugation from the peripheral venous blood of the subjects before antiviral therapy. Total cellular RNA was extracted using the TRizol Reagent (Invitrogen, Carlsbad, CA) in accordance with the manufacturer's instructions. RNA yield and purity were determined by measuring the absorbance at 260/ $280 \mathrm{~nm}$ on a NanoDrop spectrophotometer (Thermo Fisher Scientific, Waltham, Massachusetts, USA). 
mRNA expression of TLR genes in PBMCs

To quantify mRNA expression of TLR genes (including TLR 2, 3, 4, 7, and 9) in PBMCs, we performed quantitative reverse transcription polymerase chain reactions (QRT-PCR) with a LightCycler 480 system (Roche Diagnostics GmbH, Mannheim, Germany). The reagent mixture was prepared according to the protocol provided by the manufacturer (Roche Diagnostics $\mathrm{GmbH}$, Mannheim, Germany). Total RNA (2 $\mu \mathrm{g})$ was extracted from PMBCs and cDNA was generated using an oligo $(\mathrm{dT})_{18}$ primer (GeneMark Taiwan). PCR was performed in a $10-\mu$ l reaction mixture containing $2 \times$ LightCycler 480 SYBR Green I Master mix (5 $\mu$ l) (Roche Diagnostics $\mathrm{GmbH}$, Mannheim, Germany), forward and reverse primers $(0.5 \mu \mathrm{M}$ each), and cDNA $(1 \mu \mathrm{l})$. The conditions for amplification were as follows: one cycle of $95{ }^{\circ} \mathrm{C}$ for $10 \mathrm{~min}$ and 40 cycles of $95^{\circ} \mathrm{C}$ for $10 \mathrm{~s}, 60{ }^{\circ} \mathrm{C}$ for $12 \mathrm{~s}$, and $72{ }^{\circ} \mathrm{C}$ for $20 \mathrm{~s}$. After amplification was completed, a final melting-curve analysis was performed by denaturation at $95{ }^{\circ} \mathrm{C}$, re-annealing at $65^{\circ} \mathrm{C}$ for $1 \mathrm{~min}$, and then slow heating $\left(0.1{ }^{\circ} \mathrm{C} / \mathrm{s}\right)$ to $95{ }^{\circ} \mathrm{C}$ to determine the product-specific melting temperature. The reaction chamber was then cooled to $40{ }^{\circ} \mathrm{C}$ for $30 \mathrm{~s}$ prior to opening the chamber to remove the plate, as recommended by the manufacturer. Data were analyzed using the LightCycler Software 1.5 (Roche Diagnostics GmbH, Mannheim, Germany). The threshold cycle value $(\mathrm{Ct})$ was determined using the following equation: $\Delta \mathrm{Ct}=\mathrm{Ct}$ (target gene) - Ct $(\mathrm{GAPDH})$. The expression of target genes in each sample was tested in triplicate. mRNA expression of target genes is shown as a $\log$ ratio relative to GAPDH mRNA $\left(\log 2^{-(\Delta \mathrm{Ct})}\right)$.

\section{Genetic variation in interleukin (IL)28B}

Patient IL28B genotypes ere determined with ABI TaqMan SNP genotyping assays (Applied Biosystems, Foster City, CA) and with predesigned commercial genotyping assays (ABI assay ID: C_11710096_10). Briefly, PCR primers and two allele-specific probes were designed to detect a specific Single-nucleotide polymorphism (SNP) target. PCR reactions were performed in 96-well microplates with a StepOnePlus ${ }^{\mathrm{Tm}}$ Real-Time PCR System (Applied Biosystems). Allele discrimination was achieved by fluorescence detection using the StepOne ${ }^{\mathrm{TM}}$ Software v2.1.

\section{Statistical analysis}

We analyzed differences between virological responders and non-responders using the chi-square test and Student's $t$-test. Independent factors that may have influenced the response to combination therapy were identified using stepwise multiple logistic regression analysis. We used Pearson's correlation coefficient analysis to evaluate the correlation between mRNA expression of TLRs and baseline clinical variables. A $P$-value of $<0.05$ was considered statistically significant.

\section{Results}

Comparison of baseline features in patients with RVR and non-RVR

Forty-five patients (57 \%) achieved RVR. The proportion of patients with a low viral load $\left(<4 \times 10^{5} \mathrm{IU} / \mathrm{ml}\right), \mathrm{rs} 12979860$ CC genotype, and rs8099917 TT genotype was higher in the RVR group than in the non-RVR group. In addition, the median body mass index (BMI) was lower and mRNA expression of TLR 2, 3, 4, 7, and 9 was lower in the RVR group, compared with the non-RVR group.

There were no significant differences between the RVR and non-RVR patient groups in terms of gender, ALT levels, rates of adherence to treatment, or the proportion of patients with liver cirrhosis (Table 1).

\section{Multivariate analysis of pretreatment factors associated with RVR}

Stepwise multiple logistic regression analysis revealed that mRNA expression of TLR $4<-2 \log$ (odds ratio (OR), 7.17; $95 \%$ confidence interval (CI), 1.70-30.34; $P=0.007)$, a viral load $<4 \times 10^{5} \mathrm{IU} / \mathrm{ml}(\mathrm{OR}, 7.08 ; 95 \% \mathrm{CI}$, 1.17-30.09; $P=0.008$ ), and rs 8099917 TT genotype (OR, 38.8; $95 \% \mathrm{CI}, 2.65-568.63 ; P=0.008)$ were independent predictors for RVR.

\section{Comparison of baseline features in patients with SVR and non-SVR}

Four patients who completed the treatment but not the follow-up were excluded. The remaining 75 patients were analyzed. Of these 75 patients, 45 (60\%) achieved SVR. The proportion of males and the rate of liver cirrhosis were both lower in the SVR group than in the non-SVR group. The proportion of patients with RVR, rs $12979860 \mathrm{CC}$ genotype, and rs 8099917 TT genotype were higher in the SVR group than in the non-SVR group. There were no significant differences between the SVR and non-SVR patient groups in terms of TLR expression (Table 2).

\section{Multivariate analysis of pretreatment factors associated with SVR}

Stepwise multiple logistic regression analysis revealed that non-liver cirrhosis (OR, 6.94; $95 \%$ CI, 1.22-40.0; $P=0.029)$, rs 12979860 CC genotype (OR, 6.53; $95 \%$ CI, $1.18-36.01 ; P=0.031$ ), and RVR (OR, 3.06; $95 \%$ CI, 1.01-9.28; $P=0.048)$ were independent predictors for SVR. 
Table 1 Comparisons of baseline features of patients with rapid virological response (RVR) and those with non-RVR

\begin{tabular}{|c|c|c|c|}
\hline Variables & $\operatorname{RVR}(N=45)$ & Non-RVR $(N=34)$ & $P$ value \\
\hline Sex (M:F) & $23: 22$ & 19:15 & 0.674 \\
\hline Age (median,IQR) & $60.5(52.9 \sim 67.8)$ & $53.4(43.9 \sim 63.0)$ & 0.003 \\
\hline $\mathrm{BMI}, \mathrm{Kg} / \mathrm{m}^{2}$ (median,IQR) & $23.5(21.8 \sim 24.7)$ & $26.4(23.0 \sim 29.4)$ & 0.001 \\
\hline ALT, IU/L(median,IQR) & $71.0(48.0 \sim 138.5)$ & $84.5(56.3 \sim 115.5)$ & 0.801 \\
\hline HCV viral load ( $\geq$ vs $\left.<4 \times 10^{5} \mathrm{IU} / \mathrm{ml}\right)$ & $17: 28$ & $28: 6$ & $<0.001$ \\
\hline Liver cirrhosis (yes vs. no) & $4: 41$ & $6: 28$ & 0.313 \\
\hline > 80 \% adherence (yes vs. no) & $32: 13$ & $24: 10$ & 0.960 \\
\hline rs12979860 (CC vs. CT + TT) & $43: 2$ & $24: 10$ & 0.002 \\
\hline rs 8099917 (TT vs. GG + GT) & $44: 1$ & $25: 9$ & 0.002 \\
\hline TLR2 mRNA (median,IQR) & $-1.36(-2.52 \sim 0.76)$ & $0.82(0.55 \sim 0.96)$ & 0.001 \\
\hline TLR3 mRNA (median,IQR) & $-2.66(-3.13 \sim-1.28)$ & $-1.47(-1.90 \sim-1.27)$ & 0.014 \\
\hline TLR4 mRNA (median,IQR) & $-1.85(-2.53 \sim 0.57)$ & $0.66(0.31 \sim 0.86)$ & $<0.001$ \\
\hline TLR7 mRNA (median,IQR) & $-2.41(-3.19 \sim-0.07)$ & $-0.77(-1.18 \sim-0.57)$ & 0.008 \\
\hline TLR9 mRNA (median,IQR) & $-2.44(-3.17 \sim-1.01)$ & $-0.98(-1.26 \sim-0.84)$ & 0.001 \\
\hline
\end{tabular}

\section{Correlation between mRNA expression of TLRs} and baseline clinical features

mRNA expression of TLR 2, 3, 4, 7, and 9 was correlated with HCV viral load, but was not correlated with ALT levels or liver cirrhosis (Table 3).

\section{Discussion}

In this study, we found that low TLR4 mRNA expression in PBMCs was associated with RVR in patients with $\mathrm{HCV}$ genotype 1 who received peg-IFN and RBV therapy. Univariate analysis also revealed that TLR 4 expression is lower in the SVR group than in the nonSVR group $(P=0.067)$, although it is not statistically significant. The case number in our study is limited, may be more case number is needed to reach statistically significant.

TLR4, a lipopolysaccharide-receptor, plays a critical role in pathogen recognition and activation of innate and adaptive immunity. Ten et al. studied the release of soluble TLR2 and TLR4 in plasma of 394 patients with infections (infectious mononucleosis, measles, respiratory tract infections, bacterial sepsis and candidemia) or

Table 2 Comparisons of baseline features of patients with sustained virological response (SVR) and those with non-SVR

\begin{tabular}{llll}
\hline Variables & SVR $(N=45)$ & Non-SVR $(N=30)$ & $P$ value \\
\hline Sex (M:F) & $19: 26$ & $20: 10$ & 0.038 \\
Age (median,IQR) & $59.7(51.1 \sim 67.4)$ & $56.6(45.9 \sim 64.7)$ & 0.176 \\
BMI, Kg/m² (median,IQR) & $23.9(22.4 \sim 27.1)$ & $23.7(21.4 \sim 27.8)$ & 0.787 \\
ALT, IU/L(median,IQR) & $84.0(52.0 \sim 134.5)$ & $77.0(44.8 \sim 14.8)$ & $19: 11$ \\
Viral load ( $\geq$ vs $\left.<4 \times 10^{5} \mathrm{IU} / \mathrm{ml}\right)$ & $25: 20$ & $10: 20$ & 0.423 \\
RVR (yes vs. no) & $31: 14$ & $8: 22$ & 0.503 \\
Liver cirrhosis (yes vs. no) & $2: 43$ & $21: 9$ & 0.002 \\
$>80 \%$ adherence (yes vs. no) & $32: 13$ & $20: 10$ & 0.012 \\
rs12979860 (CC vs CT+TT) & $43: 2$ & $20: 10$ & 0.918 \\
rs 8099917 (TT vs GG + GT) & $45: 0$ & $-0.96(-3.39 \sim-0.67)$ & 0.002 \\
TLR2 mRNA (median,IQR) & $-1.07(-4.05 \sim-0.74)$ & $-3.28(-4.10 \sim-2.90)$ & $<0.001$ \\
TLR3 mRNA (median,IQR) & $-3.39(-4.53 \sim-2.86)$ & $-1.02(-3.54 \sim-0.78)$ & 0.304 \\
TLR4 mRNA (median,IQR) & $-1.24(-4.05 \sim-0.96)$ & $-2.42(-4.18 \sim-2.20)$ & 0.607 \\
TLR7 mRNA (median,IQR) & $-2.76(-4.53 \sim-2.19)$ & $-2.62(-4.12 \sim-2.47)$ & 0.067 \\
TLR9 mRNA (median,IQR) & $-2.85(-4.57 \sim-2.59)$ & 0.545 \\
\hline RVR
\end{tabular}

$R V R$ rapid virological response, $B M I$ body mass index, $A L T$ alanine aminotransferase, $T L R$ toll like receptor. TLR mRNA expression levels were shown as log ratios relative to GAPDH mRNA $\left(\log 2^{-(\Delta \mathrm{Ct})}\right)$ 
Table 3 Correlation between TLR mRNA expression levels and baseline clinical factors $(N=79)$

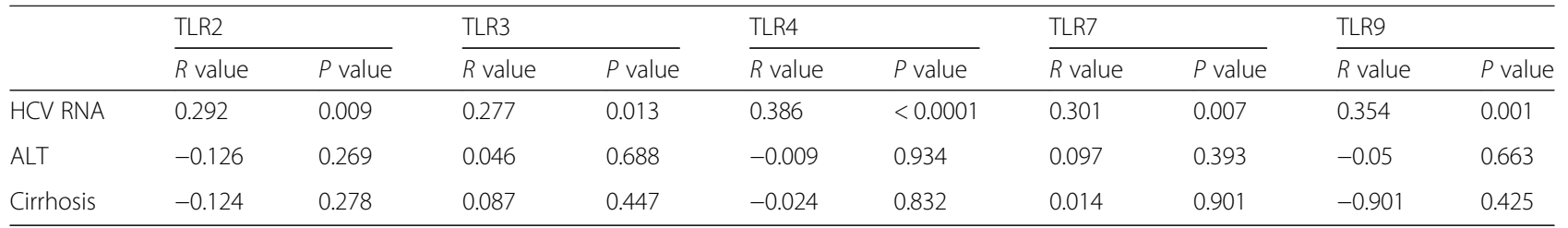

Spearman correlation. HCV RNA (log IU), ALT alanine aminotransferase (U/dl). Cirrhosis:yes vs. no. TLR mRNA expression levels were shown as log ratios relative to GAPDH mRNA $\left(\log 2^{-(\Delta C \mathrm{t})}\right)$

non-infectious inflammation (Crohn's disease, gout, rheumatoid arthritis, autoinflammatory syndromes and pancreatitis). They found that soluble TLR4 had a similar capacity for differentiating infectious and noninfectious inflammation compared to $\mathrm{C}$ reactive protein (CRP), and suggest the possibility to use soluble TLRs as diagnostic tool in inflammatory conditions [34].

Machida et al. reported that $\mathrm{HCV}$ non-structural 5A (NS5A) protein, which plays a potential role in resistance to IFN- $\alpha$ treatment, transactivates the TLR4 promoter in vitro, resulting in increased transcription of TLR4 [29].

He et al. enrolled $15 \mathrm{HCV}$ infected patients who had received a 48-week treatment with peg-IFN and RBV. They found that baseline PBMC TLR 2 and 3 mRNA levels were significantly higher in patients with SVR than in non-responders. They suggested that TLR $2 / 3$, which was up-regulated in PBMCs, might act as an adjuvant receptor, increasing not only the sensitivity to $\mathrm{HCV}$ PAMPs but also the sensitivity to INF- $\alpha$ treatment, and subsequently increased effective antiviral responses [35]. However, the number of cases examined was small.

Yuki et al. reported that low hepatic TLR3 expression was a predictor of SVR to peg-IFN plus RBV in patients with HCV genotype 1 [36]. TLRs are known to be intrahepatic interferon stimulated genes (ISGs) and these results were consistent with previous studies which found that pre-activation of intra-hepatic ISGs was associated with non-response in $\mathrm{HCV}$-infected patients [37-40]. Activation of the endogenous IFN system in HCVinfected patients was ineffective in clearing the infection and even impeded the response to therapy, most likely by inducing a refractory state in the IFN signaling pathway [37-40]. However, analyzing gene expression in liver biopsy specimens requires an invasive procedure.

In this study, we found that mRNA expression of TLR 2, 3, 4, 7, and 9 was correlated with HCV viral load. TLR activation upon exposure to HCV may subsequently limit HCV replication [25, 26, 28, 31, 32]. However, HCV can escape host immunity via several methods and sustain a chronic infection [30, 41, 42]. These interactions between HCV and TLRs may be one reason for the correlation between TLR expression and HCV viral load observed in our study.

\section{Conclusion}

Low PMBC TLR 4 levels were correlated with RVR, which indicates that TLR4 may play a critical role in $\mathrm{HCV}$ recognition and activation of innate and adaptive immunity. mRNA expression of TLRs was correlated with HCV viral load, which indicates that TLR activation upon exposure to $\mathrm{HCV}$ may subsequently limit $\mathrm{HCV}$ replication.

\section{Additional file}

Additional file 1: Raw data of these population. (XLS $79 \mathrm{~kb}$ )

\begin{abstract}
Abbreviations
AASLD, American Association for the Study of Liver Diseases; ALT, Alanine Aminotransferase; $\mathrm{BMI}$, body mass index; $\mathrm{CRP}, \mathrm{C}$ reactive protein; $\mathrm{Ct}$, threshold cycle value; DAAs, direct antiviral agents; DM, diabetes mellitus; EASL, European Association for the Study of the Liver; EVR, early virological response; HCC, hepatocellular carcinoma; HCV, hepatitis C virus; IFN, interferon; ISGs, interferon stimulated genes; NAFLD, Non-alcoholic fatty liver disease; NASH, non-alcoholic steatohepatitis; NS5A, non-structural 5A; PAMPs, pathogen-associated molecular patterns; PBMCs, peripheral blood monocytes; PEG-IFN, pegylated interferon; QRT-PCR, quantitative reverse transcription polymerase chain reactions; RBV, ribavirin; RGT, response-guided therapy; RVR, rapid virological response; SVR, sustained virological response; TLRs, Toll-like receptors
\end{abstract}

\section{Acknowledgments}

This study was supported by Grant CMRPG8A0071 from the Chang Gung Memorial Hospital-Kaohsiung Medical Center, Taiwan.

\section{Funding}

This study was supported by Grant CMRPG8A0071 from the Chang Gung Memorial Hospital-Kaohsiung Medical Center, Taiwan. The funders had no role in study design, data collection and analysis, decision to publish, or preparation of the manuscript.

\section{Availability of data and materials}

All datasets were presented in the Additional file 1.

\section{Authors' contributions}

Conception and design of study: $\mathrm{YH}-\mathrm{Y}$. Acquisition of data: $\mathrm{TH}-\mathrm{H}$. Analysis and interpretation of data: SN-L. Drafting the manuscript: CM-L. Revising the manuscript critically for important intellectual content: $\mathrm{JH}-\mathrm{W}, \mathrm{CH}-\mathrm{H}$ and $\mathrm{CH}-\mathrm{C}$. All authors read and approved the final manuscript.

\section{Competing interests}

The authors declare that they have no competing interests.

Consent for publication

The use of study data was approved by the ethical committee of Chang Gung Memorial Hospital. 


\section{Ethics approval and consent to participate}

The study protocol adhered to the ethical guidelines of the 2013 Declaration of Helsinki and was approved by the ethical committee of Chang Gung Memorial Hospital (reference number: 101-2004C). Written informed consent was obtained from each of the participants in this study.

Received: 8 December 2015 Accepted: 14 July 2016

Published online: 25 July 2016

\section{References}

1. Alberti A, Vario A, Ferrari A, Pistis R. Review article: chronic hepatitis C-natural history and cofactors. Aliment Pharmacol Ther. 2005;22 Suppl 2:74-8.

2. Shepard CW, Finelli L, Alter M. Global epidemiology of hepatitis C virus infection. Lancet Infect Dis. 2005;5:558-67.

3. El Serag HB. Hepatocellular carcinoma and hepatitis $C$ in the United States. Hepatology. 2002;36:S74-83.

4. Lauer GM, Walker BD. Hepatitis C virus infection. N Engl J Med. 2001;345:41-52

5. Seeff LB. Natural history of chronic hepatitis C. Hepatology. 2002;36:S35-46

6. Lee CM, Lu SN, Changchien CS, Yeh CT, Hsu TT, Tang JH, et al. Age, gender, and local geographic variations of viral etiology of hepatocellular carcinoma in a hyperendemic area for hepatitis B virus infection. Cancer. 1999;86:1143-50.

7. Charlton MR, Kondo M, Roberts SK, Steers JL, Krom RA, Wiesner RH. Live transplantation for cryptogenic cirrhosis. Liver Transpl Surg. 1997;3:359-64.

8. McCullough AJ. Update on nonalcoholic fatty liver disease. J Clin Gastroenterol. 2002;34:255-62.

9. Sass DA, Chang P, Chopra KB. Nonalcoholic fatty liver disease: a clinical review. Dig Dis Sci. 2005;50:171-80.

10. Blachier M, Leleu H, Peck-Radosavljevic M, Valla DC, Roudot-Thoraval F. The burden of liver disease in Europe: a review of available epidemiological data. J Hepatol. 2013;58:593-608.

11. Stepanova M, Henry L, Garg R, Kalwaney S, Saab S, Younossi Z. Risk of de novo post-transplant type 2 diabetes in patients undergoing liver transplant for non-alcoholic steatohepatitis. BMC Gastroenterol. 2015:15:175.

12. Nousbaum JB, Pol S, Nalpas B, Landais P, Berthelot $P$, Bréchot $C$, et al. Hepatitis C virus type $1 \mathrm{~b}$ (II) infection in France and Italy. Collaborative Study Group. Ann Intern Med. 1995;122:161-8.

13. McOmish F, Yap PL, Dow BC, Follett EA, Seed C, Keller AJ, et al. Geographical distribution of hepatitis $C$ virus genotypes in blood donors: an international collaborative survey. J Clin Microbiol. 1994;32:884-92.

14. Kao JH, Chen PJ, Lai MY, Yang PM, Sheu JC, Wang TH, et al. Genotypes of hepatitis $C$ virus in Taiwan and the progression of liver disease. J Clin Gastroenterol. 1995;21:233-7.

15. Lee CM, Lu SN, Hung CH, Tung WC, Wang JH, Tung HD, et al. Hepatitis C virus genotypes in southern Taiwan: prevalence and clinical implications. Trans R Soc Trop Med Hyg. 2006;100:767-74.

16. Lee CM, Hung CH, Lu SN, Wang JH, Tung HD, Huang WS, et al. Viral etiology of hepatocellular carcinoma and HCV genotypes in Taiwan. Intervirology. 2006:49:76-81.

17. Manns MP, McHutchison JG, Gordon SC, Rustgi VK, Shiffman M, Reindollar R, et al. Peginterferon alfa-2b plus ribavirin compared with interferon alfa-2b plus ribavirin for initial treatment of chronic hepatitis C: a randomised trial. Lancet. 2001;358:958-65.

18. Fried MW, Shiffman ML, Reddy KR, Smith C, Marinos G, Gonçales Jr FL, et al. Peginterferon alfa-2a plus ribavirin for chronic hepatitis $C$ virus infection. N Engl J Med. 2002;347:975-82

19. Hadziyannis SJ, Sette Jr H, Morgan TR, Balan V, Diago M, Marcellin P, et al. PEGASYS International January 2006 American Gastroenterological Association 253 Study Group. Peginterferon-a-2a and ribavirin combination therapy in chronic hepatitis C: a randomized study of treatment duration and ribavirin dose. Ann Intern Med. 2004;140:346-55.

20. Liu CH, Liu CJ, Lin CL, Liang CC, Hsu SJ, Yang SS, et al. Pegylated interferonalpha-2a plus ribavirin for treatment-naive Asian patients with hepatitis $C$ virus genotype 1 infection: a multicenter, randomized controlled trial. Clin Infect Dis. 2008;47:1260-9.

21. European Association for the Study of the Liver. EASL recommendations on treatment of hepatitis C 2015. J Hepatol. 2015:63:199-236.

22. AASLD/ISDA HCV Guidance Panel. Hepatitis C guidance: AASLD-IDSA recommendations for testing, managing, and treating adults infected with hepatitis C virus. Hepatology. 2015;62:932-54.

23. Fearon DT, Locksley RM. The instructive role of innate immunity in the acquired immune response. Science. 1996;272:50-3.
24. Biron CA. Role of early cytokines, including $\alpha$ and $\beta$ interferons (IFN- $\alpha / \beta$ ), in innate and adaptive immune responses to viral infections. Semin Immunol. 1998;10:383-90

25. Meylan E, Tschopp J. Toll-like receptors and RNA helicases: two parallel ways to trigger antiviral responses. Mol Cell. 2006;22:561-9.

26. Kawai T, Akira S. Innate immune recognition of viral infection. Nat Immunol. 2006;7:131-7.

27. Kawai T, Akira S. TLR signaling. Cell Death Differ. 2006;13:816-25.

28. Dolganiuc A, Oak S, Kodys K, Golenbock DT, Finberg RW, Kurt-Jones E, Szabo $G$, et al. Hepatitis $C$ core and nonstructural 3 proteins trigger toll-like receptor 2-mediated pathways and inflammatory activation. Gastroenterology. 2004;127:1513-24.

29. Machida K, Cheng KT, Sung VM, Levine AM, Foung S, Lai MM, et al. Hepatitis $C$ virus induces toll-like receptor 4 expression, leading to enhanced production of beta interferon and interleukin-6. J Virol. 2006:80:866-74.

30. Li K, Foy E, Ferreon JC, Nakamura M, Ferreon AC, Ikeda M, et al. Immune evasion by hepatitis C virus NS3/4A protease-mediated cleavage of the Tolllike receptor 3 adaptor protein TRIF. Proc Natl Acad Sci. 2005;102:2992-7.

31. Lee J, Wu CC, Lee KJ, Chuang TH, Katakura K, Liu YT, et al. Activation of antihepatitis C virus responses via Toll-like receptor 7. Proc Natl Acad Sci. 2006; 103:1828-33.

32. Takeshita F, Suzuki K, Sasaki S, Ishii N, Klinman DM, Ishii KJ, et al. Transcriptional regulation of the human TLR9 gene. J Immunol. 2004;173:2552-61.

33. Fukuda K, Tsuchihara K, Hijikata M, Nishiguchi S, Kuroki T, Shimotohno K, et al. Hepatitis $C$ virus core protein enhances the activation of the transcription factor, Elk1, in response to mitogenic stimuli. Hepatology. 2001;33:159-65.

34. Ten Oever J, Kox M, van de Veerdonk FL, Mothapo KM, Slavcovici A, Jansen $\mathrm{TL}$, et al. The discriminative capacity of soluble Toll-like receptor (STLR)2 and sTLR4 in inflammatory diseases. BMC Immunol. 2014;15:55.

35. He Q, Graham CS, Durante Mangoni E, Koziel MJ, et al. Differential expression of toll-like receptor mRNA in treatmen $t$ non-responders and sustained virologic responders at baseline in patients with chronic hepatitis C. Liver Int. 2006:26:1100-10.

36. Yuki N, Matsumoto S, Kato M, Yamaguchi T. Hepatic Toll-like receptor 3 expression in chronic hepatitis $\mathrm{C}$ genotype 1 correlates with treatment response to peginterferon plus ribavirin. J Viral Hepat. 2010;17:130-8.

37. Sarasin-Filipowicz M, Oakeley EJ, Duong FH, Christen V, Terracciano L, Filipowicz W, et al. Interferon signaling and treatment outcome in chronic hepatitis C. Proc Natl Acad Sci. 2008;105:7034-9.

38. Chen L, Borozan I, Feld J, Sun J, Tannis LL, Coltescu C, et al. Hepatic gene expression discriminates responders and nonresponders in treatment of chronic hepatitis C viral infection. Gastroenterology. 2005;128:1437-44.

39. Asselah T, Bieche I, Narguet S, Sabbagh A, Laurendeau I, Ripault MP, et al. Liver gene expression signature to predict response to pegylated interferon plus ribavirin combination therapy in patients with chronic hepatitis C. Gut. 2008;57:516-24.

40. Sarasin-Filipowicz M, Wang X, Yan M, Duong FH, Poli V, Hilton DJ, et al. Alpha interferon induces long-lasting refractoriness of JAK-STAT signaling in the mouse liver through induction of USP18/UBP43. Mol Cell Biol. 2009;29:4841-51.

41. Otsuka M, Kato N, Moriyama M, Taniguchi H, Wang Y, Dharel N, et al. Interaction between the HCV NS3 protein and the host TBK1 protein leads to inhibition of cellular antiviral responses. Hepatology. 2005;41:1004-12.

42. Abe T, Kaname Y, Hamamoto I, Tsuda Y, Wen X, Taguwa S, et al. Hepatitis C virus nonstructural protein 5A modulates the toll-like receptor-MyD88dependent signaling pathway in macrophage cell lines. J Virol. 2007;81: 8953-66.

\section{Submit your next manuscript to BioMed Central and we will help you at every step:}

- We accept pre-submission inquiries

- Our selector tool helps you to find the most relevant journal

- We provide round the clock customer support

- Convenient online submission

- Thorough peer review

- Inclusion in PubMed and all major indexing services

- Maximum visibility for your research

Submit your manuscript at www.biomedcentral.com/submit 